\title{
Transformation of Indian Agriculture through Mechanization
}

\author{
Radhey Shyam Singh* and Ramesh Kumar Sahni
}

ICAR-Central Institute of Agricultural Engineering, Nabi Bagh, Berasia Road, Bhopal, India

*Corresponding author: rssingh123@yahoo.com

\begin{abstract}
India accounts for only about $2.4 \%$ of the world's geographical area and $4 \%$ of its water resources, but has to support about $17 \%$ of the world's human population and $15 \%$ of the livestock. Agriculture is an important sector of the Indian economy, accounting for $17 \%$ of the nation's GDP, about $11 \%$ of its exports, about half of the population still relies on agriculture as its principal source of income and it is a source of raw material for a large number of industries. Accelerating the growth of agriculture production is therefore necessary to meet the rising demand for food, but also to increase incomes of those dependent on agriculture to ensure inclusiveness. The productivity of farms depends greatly on the availability and judicious use of farm power by the farmers. Agricultural implements and machines enable the farmers to employ the power judiciously for production purposes. Agricultural machines increase productivity of land and labour by meeting timeliness of farm operations and increase work out-put per unit time. Besides its paramount contribution to the multiple cropping and diversification of agriculture, mechanization also enables efficient utilization of inputs such as seeds, fertilizers and irrigation water. Mechanization in agriculture enhances production and productivity of crops through timeliness, better management of inputs, improved quality of work and reduction of post-harvest losses. The study revealed that the domestic sale of tractor is the highest (45.41\%) for the $41-50 \mathrm{hp}$ range followed by $36 \%$ for the $31-40 \mathrm{hp}$ range during 2015-16. The demand of high power category tractors in India increased for using high capacity farm machines on custom hiring basis. The states of Uttar Pradesh, Rajasthan, Madhya Pradesh and Maharashtra together account for about 45.21\% of the total tractors sale in India during 2015-16. The net area sown by a tractor was 487 ha during 1975-76 and reduced to 24 ha by 2015-16 that still lags behind the developed countries and even some of the developing countries of the world (e.g. China) in terms of the net area sown by a tractor. Farm power availability of India was $0.48 \mathrm{~kW} / \mathrm{ha}$ in $1975-76$ reached to $2.13 \mathrm{~kW} /$ ha in 2015-16, which is 4.44 times higher over a period of forty years. A positive direct correlation was found between available farm power, food grain productivity and cropping intensity for the country. With the increase in intensity of cropping, the turnaround time is drastically reduced and it is not possible to harvest and thresh the standing crop, on one hand, and prepare seed bed and do timely sowing operations of subsequent crop, on the other hand, in the limited time available, unless adequate farm power and matching implement is available.

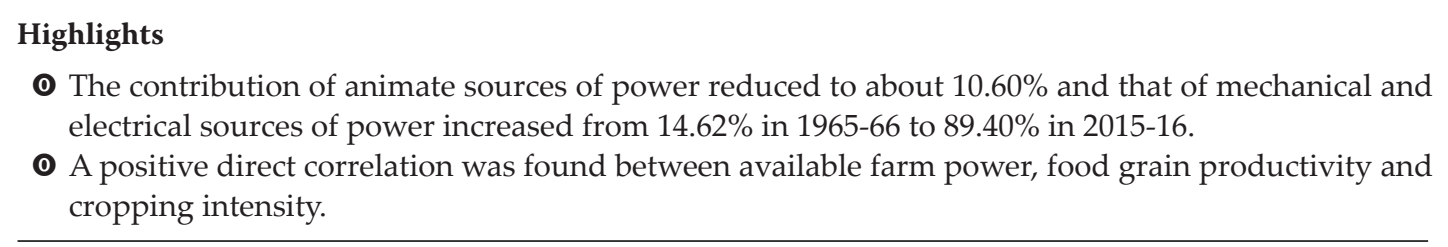

Keywords: Tractor manufacturers, tractor industry, farm machines, custom hiring, farm power availability, food grain productivity, cropping intensity

The agriculture sector in India has witnessed a considerable decline in the use of animal and human power in agriculture related activities. The trend has paved a way for a range of agricultural tools. A large number of these are driven by fossil fuel operated vehicles such as tractors, diesel engines. This has resulted in a shift from the traditional agriculture process to a more mechanized process. The role of tractors in the Indian agriculture sector reflects the growing trend of tractorisation 
in the country. Custom hiring of farm equipment is a prevalent practice in India, especially among small land owners who find ownership of large farm machines expensive and uneconomical. The government is therefore promoting farm as well as supporting bulk buying through front-end agencies. The government also provides credit and financial assistance to support local manufacturing of farm mechanization equipment. Given the labour scarcity and the government's subsidy programs, adoption of farm mechanization is set to increase. Hand tools have also been developed for all levels of the value chain. However, the prevalence of these tools comes with the issue of safety. Thus, developing farm machinery more suited to the local conditions is essential so that injuries and problems that come with the use of hand tools can be abated while making agricultural practices more productive. A sustainable productivity enhancement and the achievement of the targeted $4 \%$ growth in agriculture can therefore not be imagined without significant improvement in soil health, water management and irrigation, improved seed varieties and hybrids, and integrated pest management, credit financing and farm mechanization. Innovative technological solutions at all stages of the value chain are the key to a modern, efficient and sustainable agricultural production in India.

\section{Trend of Tractor Production and Sale}

In this direction $M$ \& M Group is the market leader with about $39 \%$ share in sale of tractors in India. Among all the tractor manufacturers of the country top five manufacturers in sale of tractors during the last seven years were the M \& M Group, TAFE Group, ESCORTS, SONALIKA \& JD, Table 1. M \& M group has maintained rank first during the period.

Table 1: Leading tractor manufactures during last seven years

\begin{tabular}{ccccc}
\hline \multirow{2}{*}{ Manufacturers } & \multicolumn{4}{c}{ Share in production, \% } \\
& $\mathbf{2 0 0 9 - 1 0}$ & $\mathbf{2 0 1 3 - 1 4}$ & $\mathbf{2 0 1 4 - 1 5}$ & $\mathbf{2 0 1 5 - 1 6}$ \\
\hline M\&M GROUP & 39.55 & 40.08 & 36.97 & 38.13 \\
TAFE GROUP & 22.59 & 24.88 & 23.81 & 22.79 \\
ESCORTS & 13.12 & 10.13 & 9.56 & 9.10 \\
SONALIKA & 8.21 & 0.83 & 12.64 & 12.02 \\
JD & 8.74 & 9.63 & 7.10 & 8.23 \\
\hline
\end{tabular}

Domestic sale trend revealed a continuous upward during up to 2013-14 and slightly decreased during 2014-15 \& 2015-16. Domestic sale during 2004-05 was 241757 units increased to 482237 units during 2010-11 and registered CAGR of $12.73 \%$. Sizeable rising sale trend was again maintained up to 201314 with 633846 units and shown a CAGR of $10.18 \%$. CAGR for the overall period (2005-06 to 2015-16) was found $5.83 \%$, Fig. 1 . The increasing trend in sale of tractors over the years indicated a rising acceptance of agricultural machines and equipment with the Indian farmers.

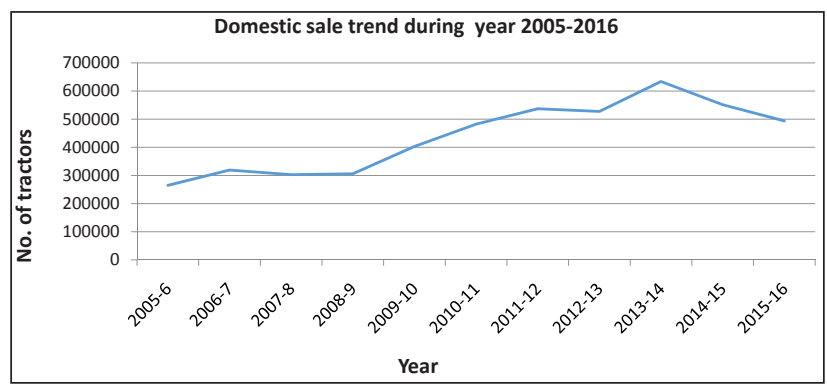

Fig. 1: Domestic tractor sale trend in India

Source: Tractor Manufacturers Association (TMA)

Regarding exports, India of latter has been exporting tractors to a number of countries, but predominantly to Sri Lanka, Nepal and USA. Since Indian tractors confirm to the international standard by virtue of their foreign collaboration it is possible for India to export to more tractors to the rice and wheat growing countries.

Export trend of tractor during the period 2005-06 to 2015-16 was analyzed and shown in Fig. 2. Export of various hp of tractors during 2005-06 was 43553 units increased to 77485 units in 2015 -16 registered a CAGR of $5.93 \%$.

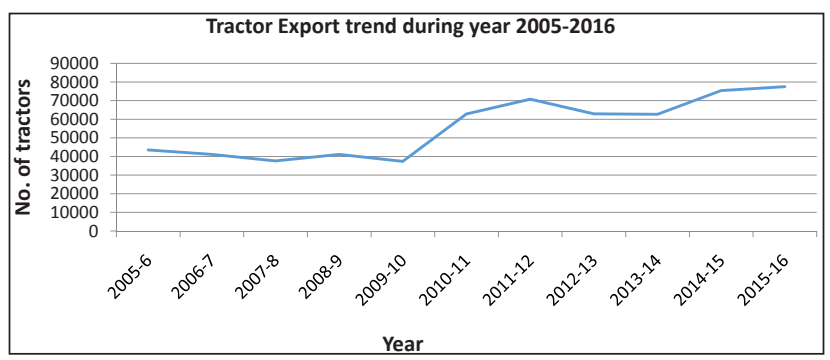

Fig. 2: Tractor export trend

Source: Tractor Manufacturers Association (TMA)

\section{Horse Power Wise Tractor Sale by different Manufacturers}

Horse power wise tractor produced by different 
manufacturers was revealed that in the range of $<$ $20 \mathrm{hp}, \mathrm{M} \& \mathrm{M}$ GROUP ranked first followed by VST and SONALIKA during 2015-16. M\&M GROUP again ranked first in 41-50 hp group followed by TAFE GROUP, SONALIKA \& ESCORTS during 2015-16. In the range of 21-30 hp, M\&M GROUP again took first rank followed by TAFE GROUP \& FORCE MOTORS. M\&M GROUP again ranked first with 74164 units production followed by TAFE GROUP, ESCORTS \& SONALIKA during 2013-14 in the 31-40 hp range. Range of 41-50 hp are the most preferred range in which, M\&M GROUP stood first followed by TAFE GROUP, ESCORTS, JD \& SONALIKA. In high hp range $>50$, JD ranked first followed by SONALIKA, M\& M GROUP and NHI for the year 2013-14. Thus, the industry is started polarization with higher growth in the upper and lower power segments.

Horse power wise tractor sold by different manufacturers was also analysed. In the range of $<$ $20 \mathrm{hp}, \mathrm{M} \& \mathrm{M}$ GROUP ranked first followed by VST and SONALIKA during 2015-16. In the range of 21-30 hp, M\&M GROUP again registered first rank followed by TAFE GROUP \& FORCE MOTORS. M\&M GROUP again ranked first with sold units of 69104 followed by TAFE GROUP, ESCORTS \& SONALIKA during 2015-16 in the 31-40 hp range. Range of 41-50 hp are the most preferred range in which, M\&M GROUP stood first followed by TAFE GROUP, SONALIKA, ESCORTS \& JD. In high hp range $>50, M \& M$ GROUP ranked first followed by JD, SONALIKA, and NHI for the year 2015-16, Fig. 3.

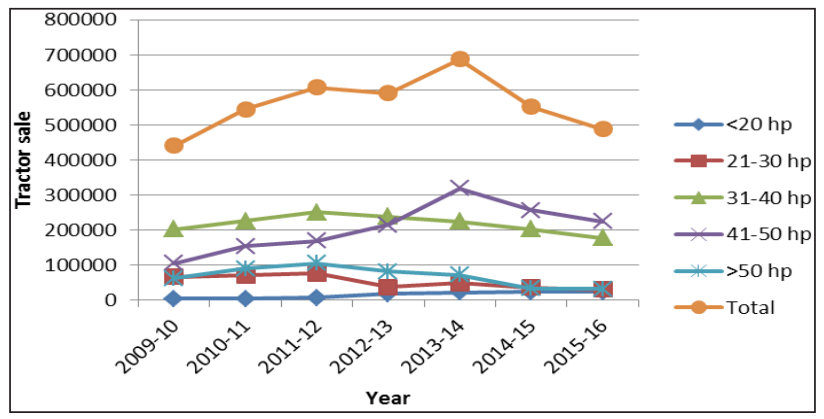

Fig. 3: Tractor sale in different hp range

\section{State wise sale of tractors during 2015-16}

Tractors sale in Uttar Pradesh was found highest with 71527 units during 2015-16 followed by Rajasthan (501851 units), Madhya Pradesh (48375 units), Maharashtra (42125 units), Gujarat (39792) units \& Bihar (35402), Fig 4. The demand of tractors is increasing in these states due to an increase in use of tractors for construction works.

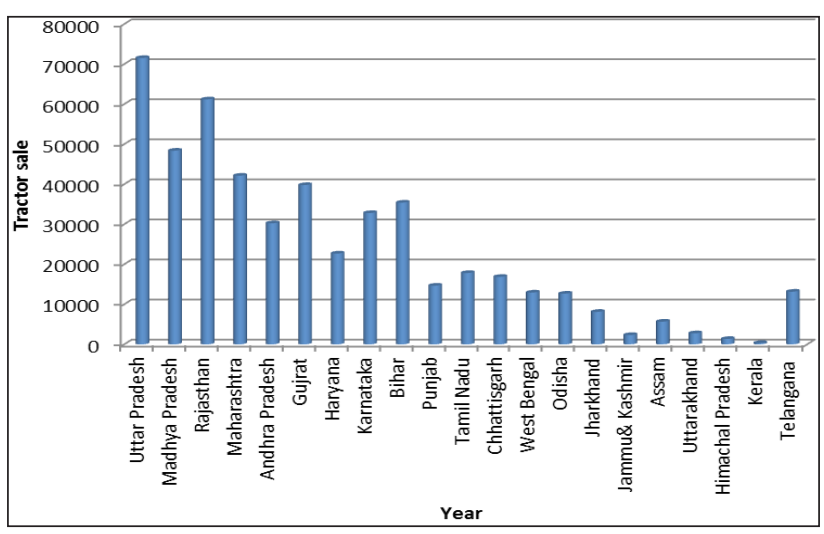

Fig. 4: State wise sale of tractors

Recent data on sale of tractors revealed that growth has been relatively higher in those states where tractor penetration in agriculture was initially low. Thus, over the previous decade, eastern part of India has emerged as the major market of tractors, Fig. 4.

\section{Power Availability}

For adoption of higher level of technology to perform complex operations within time constraints and with comfort and dignity to the operators, mechanical power becomes essential. Thus, the extent of use of mechanical power serves as an indicator of acceptance of higher level of technology on farms.

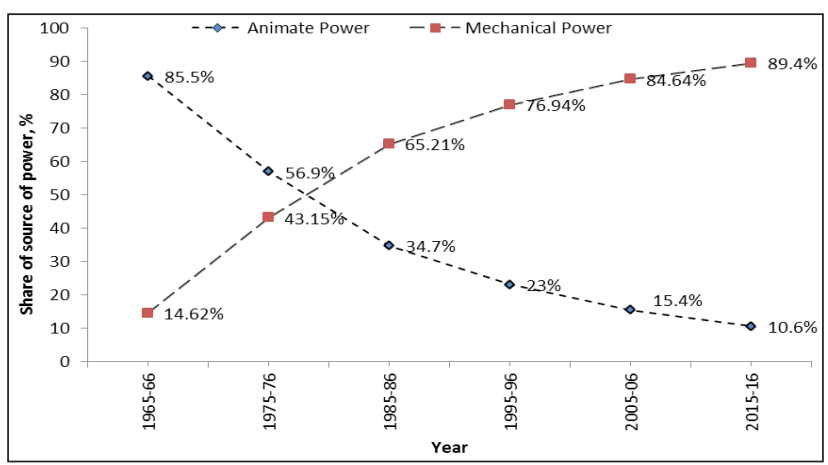

Fig. 5: Scenario of animate \& mechanical farm power

Tractor growth in the country in terms of production and sale was many folds. A tractor could be found after every 24 ha cultivated area in span of 51 years. The results of various studies confirm that in those states where agricultural mechanization has made good progress, its benefits are being shared by all 
CD Singh and Sahni

Table 2: Horse power wise tractor production by different manufacturers

\begin{tabular}{|c|c|c|c|c|c|c|c|c|}
\hline Manufacturers & hp range & 2009-10 & 2010-11 & 2011-12 & 2012-13 & 2013-14 & 2014-15 & 2015-16 \\
\hline VST & $<20 \mathrm{hp}$ & 3752 & 4602 & 7219 & 7901 & 7637 & 7451 & 7834 \\
\hline ESCORTS & & - & - & - & - & 110 & 344 & 653 \\
\hline M\&M GROUP & & - & - & - & 9551 & 12989 & 12862 & 12127 \\
\hline TAFE GROUP & & - & - & - & 919 & 46 & 0 & 0 \\
\hline SONALIKA & & - & - & - & 357 & 2562 & 3864 & 2822 \\
\hline TOTAL & & 3752 & 4602 & 7219 & 18728 & 23344 & 24521 & 23436 \\
\hline FORCE MOTORS & $21-30 \mathrm{hp}$ & 211 & 499 & 1118 & 955 & 2171 & 2813 & 3460 \\
\hline ESCORTS & & 8887 & 8953 & 8532 & 1766 & 440 & 256 & 355 \\
\hline HMT & & 695 & 541 & 349 & 465 & 129 & 108 & 41 \\
\hline M\&M GROUP & & 32121 & 37558 & 45402 & 8419 & 22277 & 18126 & 14834 \\
\hline TAFE GROUP & & 19701 & 19999 & 23067 & 21093 & 18206 & 13168 & 8943 \\
\hline SONALIKA & & 3281 & 1885 & 1949 & 3105 & 1936 & 2281 & 3736 \\
\hline TOTAL & & 64896 & & 80417 & 35803 & 45159 & 36752 & 31369 \\
\hline FORCE MOTORS & $31-40 \mathrm{hp}$ & 283 & 269 & 380 & 308 & 408 & 402 & 442 \\
\hline ESCORTS & & 19041 & 20032 & 19243 & 25580 & 32590 & 28349 & 24023 \\
\hline HMT & & 3373 & 3168 & 2791 & 1284 & 1025 & 732 & 439 \\
\hline M\&M GROUP & & 83921 & 102853 & 104327 & 89144 & 91828 & 73814 & 74164 \\
\hline TAFE GROUP & & 61701 & 70528 & 93828 & 80398 & 67892 & 59161 & 53650 \\
\hline JD & & 5917 & 7418 & 8810 & 5946 & 7612 & 5340 & 4995 \\
\hline NHI & & 5118 & 5803 & 5874 & 6390 & 6269 & 6926 & 5898 \\
\hline SAME DEUTZ-FAHR & & 345 & 240 & 108 & 88 & 28 & 5 & 86 \\
\hline SONALIKA & & 17983 & 21177 & 34979 & 24559 & 25031 & 26401 & 23172 \\
\hline TOTAL & & 197682 & & 270340 & 233697 & 232683 & 201130 & 186869 \\
\hline FORCE MOTORS & $41-50 \mathrm{hp}$ & 122 & 329 & 384 & 389 & 680 & 1274 & 1074 \\
\hline ESCORTS & & 28890 & 37054 & 34782 & 30416 & 35056 & 25707 & 24496 \\
\hline HMT & & 373 & 458 & 665 & 373 & 204 & 123 & 109 \\
\hline M\&M GROUP & & 28023 & 40790 & 47654 & 90462 & 140377 & 108441 & 104424 \\
\hline TAFE GROUP & & 13495 & 19239 & 26754 & 35773 & 79677 & 65676 & 59467 \\
\hline JD & & 10839 & 16440 & 19240 & 15824 & 25748 & 18250 & 17831 \\
\hline NHI & & 16215 & 27091 & 30179 & 19565 & 20170 & 18522 & 15252 \\
\hline SAME DEUTZ-FAHR & & 1052 & 1160 & 1078 & 1209 & 1193 & 1075 & 803 \\
\hline SONALIKA & & 6833 & 12997 & 14746 & 17115 & 20980 & 25894 & 24637 \\
\hline TOTAL & & 105842 & 155558 & 175482 & 211126 & 324085 & 264962 & 248093 \\
\hline ESCORTS & $>51 \mathrm{hp}$ & 0 & 0 & 0 & 1651 & 2401 & 3949 & 2457 \\
\hline HMT & & 211 & 643 & 621 & 401 & 188 & 115 & 44 \\
\hline M\&M GROUP & & 27268 & 37329 & 49610 & 25024 & 11819 & 13367 & 12373 \\
\hline TAFE GROUP & & 2966 & 4321 & 6781 & 5008 & 7552 & 7947 & 8206 \\
\hline JD & & 21101 & 29714 & 32739 & 19629 & 18321 & 19957 & 24190 \\
\hline SAME DEUTZ-FAHR & & 2020 & 4340 & 5744 & 3853 & 4596 & 9857 & 9473 \\
\hline SONALIKA & & 7469 & 10967 & 10943 & 14794 & 16567 & 19020 & 14313 \\
\hline NHI & & 0 & 0 & 0 & 8976 & 10086 & 11417 & 10742 \\
\hline TOTAL & & 61035 & 87314 & 106438 & 79336 & 71530 & 85629 & 81798 \\
\hline FORCE MOTORS & $\begin{array}{l}\text { All Manufac- } \\
\text { turers }\end{array}$ & 616 & 1097 & 1882 & 1652 & 3259 & 4489 & 4976 \\
\hline ESCORTS & & 56818 & 66039 & 62557 & 59413 & 70597 & 58605 & 51984 \\
\hline HMT & & 4652 & 4810 & 4426 & 2523 & 1546 & 1078 & 633 \\
\hline M\&M GROUP & & 171333 & 218530 & 246993 & 222600 & 279290 & 226610 & 217922 \\
\hline TAFE GROUP & & 97863 & 114087 & 150430 & 143191 & 173373 & 145952 & 130266 \\
\hline VST & & 3752 & 4602 & 7219 & 7901 & 7637 & 7451 & 7834 \\
\hline
\end{tabular}




\begin{tabular}{cccccccc} 
JD & 37857 & 53572 & 60789 & 41399 & 67076 & 43547 & 47016 \\
NHI & 21333 & 32894 & 36053 & 34931 & 51681 & 36865 & 31892 \\
SAME DEUTZ-FAHR & 3417 & 5740 & 6930 & 5150 & 36525 & 10937 & 10362 \\
SONALIKA & 35566 & 47026 & 62617 & 59930 & 5817 & 77460 & $\mathbf{6 8 6 8 0}$ \\
\hline TOTAL INDUSTRY & $\mathbf{4 3 3 2 0 7}$ & $\mathbf{5 4 8 3 9 7}$ & $\mathbf{6 3 9 8 9 6}$ & $\mathbf{5 7 8 6 9 0}$ & $\mathbf{6 9 6 8 0 1}$ & $\mathbf{6 1 2 9 9 4}$ & $\mathbf{5 7 1 5 6 5}$ \\
\hline
\end{tabular}

Table 3: Cropping intensity and power availability on Indian farms

\begin{tabular}{cccccc}
\hline Year & $\begin{array}{c}\text { Cropping intensity } \\
\mathbf{( \% )}\end{array}$ & $\begin{array}{c}\text { Food grain } \\
\text { productivity } \\
\mathbf{( t / h a )}\end{array}$ & $\begin{array}{c}\text { Power available } \\
\mathbf{( k W / h a )}\end{array}$ & $\begin{array}{c}\text { Power per unit } \\
\text { production } \\
\mathbf{( k W / t )}\end{array}$ & $\begin{array}{c}\text { Net sown area per } \\
\text { tractor } \\
\mathbf{( h a )}\end{array}$ \\
\hline $1975-76$ & 120.00 & 0.944 & 0.48 & 0.51 & 487 \\
$1985-86$ & 127.00 & 1.184 & 0.73 & 0.62 & 174 \\
$1995-96$ & 131.00 & 1.50 & 1.05 & 0.70 & 84 \\
$2005-06$ & 139.22 & 1.715 & 1.71 & 1.0 & 37 \\
$2010-11$ & 140.83 & 1.930 & 1.77 & 0.92 & 36 \\
$2015-16$ & 141.70 & 2.056 & 2.13 & 1.04 & 24 \\
\hline
\end{tabular}

farmers irrespective of the size of their operational holdings and whether they own tractors and machinery or not.

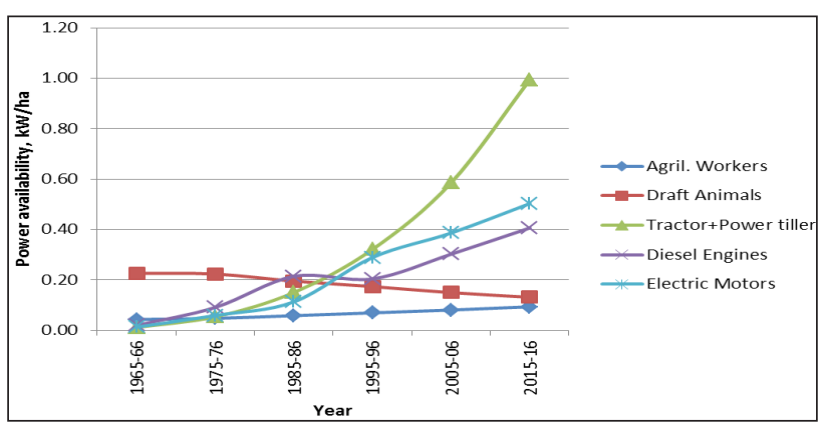

Fig. 6: Farm power availability from different sources

Over the years the shift has been towards the use of mechanical and electrical sources of power, while in $1965-66$ about $85.50 \%$ farm power was coming from animate sources. In 2015-16 the contribution of animate sources of power reduced to about $10.60 \%$ and that of mechanical and electrical sources of power increased from $14.62 \%$ in $1965-66$ to $89.40 \%$ (Fig 5-6).

\section{Cropping Intensity and Power Availability Scenario}

The cropping intensity increasing with increase in per unit power availability. It was $120 \%$ with power availability of $0.48 \mathrm{~kW} /$ ha during $1975-76$ that increased to about $141.70 \%$ per cent with increased power availability to $2.13 \mathrm{~kW} / \mathrm{ha}$ in 2015.16. Productivity and unit power availability is associated linearly, Table 3 \& Fig 7. It is also evident that farm power input has to be increased further to achieve a higher food grains production, the composition of farm power from different sources to be properly balanced to meet of its timely requirements for various farm operations.

Mechanization of cultivation of various crops has also shown increasing trend over the years as the power availability on the farm increased. The net area sown by a tractor was 487 ha during 197576 and reduced to 24 ha by 2015-16 that still lags behind the developed countries and even some of the developing countries of the world (e.g. China) in terms of the net area sown by a tractor.

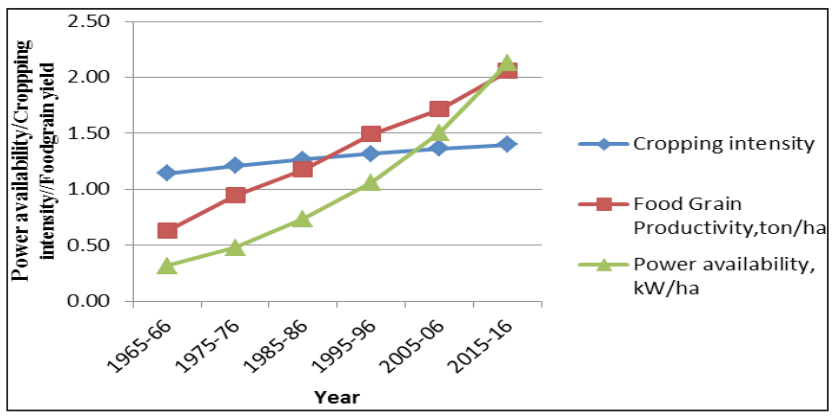

Fig. 7: Relationship between power availability, food grain productivity \& cropping intensity

The Tractors available in developed countries have advanced features and accessories that are not found in Indian tractors. Tractor industry has made a steady and satisfactory progress even in drought areas. Four factors have contributed to the steady progress:

- Government laid stress on the mechanization 
of agriculture with a view to boost food grain production. Therefore, agriculture sector started receiving financial assistance.

- There is an increase in awareness among the farmers for the need of farm mechanization and are keen to acquire tractor with the help of credit facilities from financial institutions.

- Agronomists believe that there is need for more tilling due to depletion of moisture and repeated cultivation of land. It is precisely for this reason that the demand for tractors was well maintained even during a draught period. Animal power available is too inadequate to meet power demand of our farmers.

- Mechanized operations are preferred to eliminate drudgery and delay, also labour shortage during harvesting increased the use of tractor.

\section{Government Initiatives And Programs To Boost Farm Mechanization}

The Government of India, in association with state governments, has launched several schemes over the past decade, aimed at improving farmers' access to quality farm inputs and thus increasing production and yields. Some of these are given as under:

\section{National Food Security Mission (NFSM)}

Launched in 2007 as part of the Eleventh Five Year Plan, NFSM aimed to increase production of rice, wheat and pulses by 10, 8 and $2 \mathrm{Mt}$ respectively by the end of 2011-12. The crop development scheme was approved with a budget of 49 billion for five years and aimed to improve farmers' access to technologically superior seeds, soil management and farm mechanization techniques. The mission achieved its previous target of an additional $25 \mathrm{Mt}$ of production a year before the deadline.

The interventions covered under NFSM-Rice include Cluster Demonstrations of Hybrid Rice and HYVs, cono-weeder, Manual Sprayer, Power sprayer, Drum Seeder, Pump set (up to $10 \mathrm{HP}$ ), Seed drill, Multi crop planter, Zero till multi crop planter, Power weeder, Water carrying pipes, Rotavator, Paddy Thresher/Multi crop thresher, Laser land leveler , Self-propelled paddy transplanter and assistance for custom hiring. The interventions covered under
NFSM-Wheat include Cluster Demonstrations on improved package of practices, Manual Sprayer, Power sprayer, Chiseller, Deep Ploughing, Sprinkler set, Pump set (up to $10 \mathrm{HP}$ ), Tractor mounted sprayer, Seed drill, Multi crop planter, Zero till seed drill, Zero till multi crop planter, Power weeder, water carrying pipes, mobile raingun, Rotavator/ turbo seeder, Multi crop thresher, Laser land leveler, Plant protection chemicals and Bio pesticides etc.

\section{Rashtriya Krishi Vikas Yojna (RKVY)}

Launched in August 2007, RKVY is a joint scheme of the state and central governments to boost public investment in agriculture and thus increase productivity on Indian farms. The scheme seeks to provide assistance to states in different area of agriculture value chain such as seed production and distribution, irrigation, storage and processing facilities and farm mechanization.

\section{Macro Management of Agriculture (MMA)}

Launched in 2001, MMA is a Central Governmentsponsored scheme, focusing on provision and promotion of hybrid seeds, farm mechanization and integrated cereal-development programs.

\section{Water and Irrigation Management}

Total irrigation outlay by state governments has increased by 17\% a year, on average, between 2003 and2012, reflecting state governments' efforts to increase irrigation. The Planning Commission in its $12^{\text {th }}$ Five Year Plan (2012-17) recommended outlays of ₹ 3419 billion to execute Major and Medium Irrigation (MMI) projects in India, up from ₹ 2318 billion recommended during the preceding plan.

\section{CONCLUSION}

Agricultural Mechanization industry in India is expected to grow at a rapid pace owing to the government efforts to bridge the supply and demand gap of agriculture through R\&D and technology efforts during 2013-2017. The spectacular achievement reflects the maturity and dynamism of tractor manufacturers and also the policies adopted by the government to enable it to effectively meet the demand. The tractor industry in India has made a significant progress in terms of production and capacity as well as indigenization of technology. 
Shrinking farm holdings also demands the need for mechanization so that the agricultural yield can be maximized with optimal efforts through mechanization. Volume growth in the tractor industry in the past four decades shows a compound annual growth rate (CAGR) of ten percent, despite seasonal variations that cause changes in tractor demand and subsequently impacting industry volumes. The study further revealed that the domestic sale of tractor is the highest $(45.41 \%)$ for the $41-50 \mathrm{hp}$ range followed by $36 \%$ for the $31-40 \mathrm{hp}$ range during 2015-16. The demand of high power category tractors in India increased for using high capacity farm machines on custom hiring basis. The states of Uttar Pradesh, Rajasthan, Madhya Pradesh and Maharashtra together account for about $45.21 \%$ of the total tractors sale in India during 2015-16. The net area sown by a tractor was 487 ha during 1975-76 and reduced to 24 ha by 2015-16 that still lags behind the developed countries and even some of the developing countries of the world (e.g. China) in terms of the net area sown by a tractor. Farm power availability of India was $0.48 \mathrm{~kW} / \mathrm{ha}$ in 1975-76 reached to $2.13 \mathrm{~kW} / \mathrm{ha}$ in 2015-16, which is 4.44 times higher over a period of forty years. A positive direct correlation was found between available farm power, food grain productivity and cropping intensity for the country. With the increase in intensity of cropping the turnaround time is drastically reduced and it is not possible to harvest and thresh the standing crop, on one hand, and prepare seed bed and do timely sowing operations of subsequent crop, on the other hand, in the limited time available, unless adequate farm power and matching implement is available.

\section{REFERENCES}

Agriculture Research Data Book - 2002.

http://www.iasri.res.in/agridata/02data $\% 5$ Cchapter $\% 20$ 3\%5Cdb2002tb3_41.htm.

Paliwal, J.K. 1997. Recent Development and Future Projections in Tractor Industries in India. Agricultural Engineering Today, 20-21(1-4): 58-64.

http://www.indianmba.com/Occasional_Papers/OP127/ op127.html

http://en.wikipedia.org/wiki/ Tractors_in_India

http://www.123eng.com/forum/viewtopic.php?p=16899

Agricultural Census 2011

Agricultural Statistics at a Glance, 2011, 2012, 2013.

Singh, R.S., Surendra Singh and Singh, S.P. 2015. Farm Power and Machinery Availability on Indian Farms. Agricultural Engineering Today, 39(1): 45-56.

Singh, R.S. 2013. Custom Hiring and Scope of Entrepreneurship Development in Farm Machinery, AMA, 44(2): 26-32.

Singh, R.S., Singh, S.P. and Singh Surendra. 2009. Sale of tractors of different makes in India. Agricultural Engineering Today, 33(3): 20-37.

Singh, S.P., Singh, R.S. and Singh Surendra. 2009. Tractor production and sales in India. Agricultural Engineering Today, 33(1): 20-32.

Singh Surendra. 2007. Farm machinery - Principles and applications. Directorate of Information and Publications on Agriculture, Indian council of Agricultural Research, New Delhi.

Singh Surendra, Singh, R.S. and Singh, S.P. 2010. Farm Power Availability and Agriculture Production Scenario in India. Agricultural Engineering Today, 34(1): 9-20.

Tyagi, K.K., Singh Jagbir, Kher, K.K., Jain, V.K. and Singh Surendra. 2010. A project Report on 'Study on Status and Projection Estimates of Agricultural Implements and Machinery'. IASRI New Delhi.

Tractor \& Power Tiller Manufacturers Association. 
